\title{
RESEARCH PAPER \\ Establishing Acacia salicina under dry Mediterranean conditions: The effects of nursery fertilization and tree shelters on a mid-term experiment with saline irrigation
}

\author{
Juan A. Oliet ${ }^{1}$, Rosa Planelles ${ }^{1}$, Francisco Artero ${ }^{2}$, and Juan M. Domingo- \\ Santos $^{3}$ \\ ${ }^{1}$ Departamento de Sistemas y Recursos Naturales, Universidad Politécnica de Madrid, E.T.S. Ingenieros de \\ Montes. Ciudad Universitaria s/n, 28040 Madrid, Spain. \\ ${ }^{2}$ Estación Experimental de Zonas Áridas, Consejo Superior de Investigaciones Científicas. Ctra. de \\ Sacramento s/n, 04120 La Cañada, Almería, Spain. \\ ${ }^{3}$ Departamento de Ciencias Agroforestales, Universidad de Huelva, Campus Universitario de La Rábida. \\ 21819 Palos de la Frontera, Huelva, Spain.
}

\begin{abstract}
J.A. Oliet, R. Planelles, F. Artero, and J.M. Domingo-Santos. 2016. Establishing Acacia salicina under dry Mediterranean conditions: The effects of nursery fertilization and tree shelters on a mid-term experiment with saline irrigation. Cien. Inv. Agr. 43(1):69-84. The restoration of dry lands in the Mediterranean is a challenging task because harsh abiotic conditions hamper the counteraction of feed-back degradation processes. Active restoration through planting must be performed to deter this process. In this study, we tested the influence of mineral nutrition in the nursery (two formulations of controlled release fertilizer at two rates each) and tree protection after planting (by using tube shelters) on the nine-year performance of Acacia salicina irrigated with low-quality (saline) water. The overall survival at the end of the study period was $58.2 \%$, with the electrical conductivity of the soil saturation extract reaching 5.4 $\mathrm{dS} \cdot \mathrm{m}^{-1}$ after nine years. The survival and growth (in height) were greater for seedlings fertilized with more than $1.5 \mathrm{~g} \cdot \mathrm{L}^{-1}$ of 9-13-18, although the survival differences became significant only after the seventh year. The basal stem diameter (BSD) of seedlings that were fertilized at higher rates was significantly greater than those that were fertilized at lower rates during the first two years of planting; the differences were no longer present thereafter. The seedlings in shelters had marginally superior survival, faster growth during the first four years, and smaller BSD values after the third year compared to those of the unprotected seedlings. In comparison with a parallel study that was conducted under drought conditions, irrigation reduced some differences among treatments, but it increased others. These results emphasize the importance of the size and mineral nutrient status of nursery stock in irrigated plantations under dry Mediterranean conditions, with highly fertilized seedlings showing superior performance. Long-term planting studies are crucial for gaining a greater understanding of seedling performance and for providing a better rationale for treatment recommendations.
\end{abstract}

Key words: Plantation, restoration, seedling nutrition, seedling quality, tube shelters

Received May 27, 2015. Accepted March 8, 2016.

Corresponding author: juan.oliet@upm.es 


\section{Introduction}

The rehabilitation of lands under arid conditions is one of the most challenging restoration tasks because not only does degradation itself preclude the recovery of the ecosystem, but abiotic factors such as intense droughts also reduce the productivity and the ability of the ecosystem to restart succession (Vallejo et al., 2012). Under high levels of degradation (croplands with intensive farming, surface mining, or highly eroded soils), soil systems lose most of their structural elements, resulting in limited microsite diversity (Cortina et al., 2011). In addition, many restoration projects require plant densities and spatial distribution that do not match the site's capabilities. Under these circumstances, ecotechnologies for active restoration at reasonable costs that can ameliorate microsites and reduce predation must be applied to ensure restoration (Vallejo et al., 2012). In addition, choosing species that are adapted to the site conditions (Padilla et al., 2009) and targeting quality seedlings (Villar-Salvador et al., 2012) are among the most common techniques for improving restoration success in degraded Mediterranean areas.

Plant mineral nutrition is among the most important seedling quality attribute for planting temperate forests. A growing body of research that is specific to Mediterranean areas has reemphasized the importance of plant mineral nutrition to survival and growth, supporting the ecophysiological relations between seedling traits and planting responses (Villar-Salvador et al., 2012). Those relations indicate the importance of producing large and nutrient-loaded nursery seedlings for planting success in Mediterranean and dry areas, especially with respect to N (Oliet et al., 2013 and references therein), although a question has been raised in recent years about the importance of accounting for the influence of environmental specificities in drylands to match the seedling quality and fertilization to optimize survival (Cortina et al., 2013). Incorporating controlled release fertilizer (CRF) into the growing media provides an efficient means of nutrient loading in the nursery as well as continued fertilization after outplanting (Haase et al., 2006; Oliet et al., 2013).

One of the most widespread cultural practices in Mediterranean restoration programs over the past 20 years has been the use of tube shelters (Piñeiro et al., 2013). Along with protecting seedlings from animal predation, these shelters can increase seedling survival (Oliet et al., 2003; Padilla et al., 2011). A recent meta-analysis of the use of ecotechnologies for dryland restoration emphasizes tube shelters as one of the most effective methods for improving survival (Piñeiro et al., 2013). These results suggest a positive effect of tube shelters that is related to light reduction (also Puértolas et al., 2012). However, these shelters have also been shown to reduce root growth after planting, especially in shade-intolerant species (Vázquez de Castro et al., 2014), providing a rationale for the observed survival reduction of these species (Oliet et al., 2003; Jiménez et al., 2005). New experiments with other Mediterranean species can help to create a better understanding of the seedling-shelter system and the related response on the basis of specific functional traits to improve prescriptions for use in forestation.

Irrigation of forest plantations can be necessary in Mediterranean dry areas to assure survival when the summer drought is long and severe (Padilla et al., 2011; Pardos et al., 2015). Low precipitation and the salinization of groundwater require the use of additional water resources (wastewater, desalinized water, etc.). Therefore, more information is needed to improve water management in plantations, specifically when using low-quality water resources such as those that are usually found in arid zones (Dawalibi et al., 2015). Because of the interactions between experimental treatments and time, it is important to monitor plantations for more than one season. In particular, the effects of tree shelters or the combination of nursery mineral nutrition and tree shelters may be prolonged for several seasons after planting 
(Jacobs, 2011; Oliet et al., 2000; Oliet et al., 2005). In addition, target seedling characteristics can change under Mediterranean dry conditions if irrigation is applied after outplanting. However, few studies consider more than the first year response, especially when examining the effects associated with nursery fertilization treatments.

Acacia salicina Lindl. is an N-fixing leguminous shrub or tree that is native to the arid zone of South Australia, but it has been introduced to other regions as a multipurpose species (Le Houérou, 2000; Rehman et al., 1999). It has been successfully established in degraded areas (Grigg and Mulligan, 1999), and it is highly salt and drought-tolerant (Le Houérou, 2000; Yokota, 2003). In Spain, A. salicina has been introduced in some Mediterranean areas to serve as a source of fodder for livestock (Correal et al., 1988), for ornamental uses, and to rehabilitate disturbed areas (Tilstone et al., 1998). In addition, in comparison with the other native and non-native species of arid Mediterranean lands, this species ranked highest as a soil modifier, improving the physical and chemical properties as well as the richness of vascular species under its canopy (Jeddi et al., 2009). This species is not considered invasive in the Iberian Peninsula (Ministerio de Agricultura, Alimentación y Medio Ambiente, 2013). Because of its ability to quickly modify surface properties and foster succession, this species is considered an interesting non-native candidate for the restoration of very degraded Mediterranean areas if some management prescriptions such as reducing the rotation period and controlling its spread are undertaken (Jeddi et al., 2009).

The objective of this study was to evaluate the effects of nursery fertilization and tree shelters in an irrigated experiment on mid- to long-timescale responses of planted A. salicina seedlings on degraded land in a semiarid Mediterranean region of Spain. This trial was conducted in parallel to another experiment performed without irrigation in the same plot area (Oliet et al., 2005), and we believe that a comparison of treatments with and without irrigation will provide some interesting clues about the importance of drought stress on the effects of the tested treatments.

\section{Materials and methods}

\section{Nursery production and field planting}

A. salicina seedlings were grown at the Boticario Centre ( $2^{\circ} 24^{\prime} \mathrm{W}, 36^{\circ} 52^{\prime} \mathrm{N}$, elevation $\left.60 \mathrm{~m}\right)$ in Almeria, Spain. The plants were sown in May 1992 in individual $230 \mathrm{~mL}$ cell containers filled with a 4:1 (v/v) sphagnum peat moss:vermiculite growth medium in which the fertilizer treatments were mixed. The fertilizer treatments consisted of two rates of two different controlled-release Osmocote ${ }^{\circledR}$ (Scotts Co., Marysville, OH, USA) formulations plus a non-fertilized treatment for comparison. The tested formulations and rates were as follows: $9-13-18: 9 \mathrm{~N}\left(6.1 \% \mathrm{NH}_{4}-\mathrm{N}\right.$ and $\left.2.9 \% \mathrm{NO}_{3}-\mathrm{N}\right)-5.7 \mathrm{P}-14.9 \mathrm{~K}$, at rates of 1.5 and 3.25 $\mathrm{g} \mathrm{L}^{-1}$ substrate; and $16-8-9+3 \mathrm{Mg}$ : $16 \mathrm{~N}(6.6 \%$ $\mathrm{NH}_{4}-\mathrm{N}$ and $\left.9.4 \% \mathrm{NO}_{3}-\mathrm{N}\right)-3.5 \mathrm{P}-7.5 \mathrm{~K}$, at rates of 3.25 and $7.0 \mathrm{~g} \mathrm{~L}^{-1}$ substrate. Each formulation had a nutrient release period of 12-14 months at $21{ }^{\circ} \mathrm{C}$. Micromax ${ }^{\circledR}$ (Scotts Co.), which is a solid mixture of microelements, was added to all the treatments at a rate of $0.15 \mathrm{~g} \mathrm{~L}^{-1}$. The fertilizer treatments were designed to supply an increasing amount of $\mathrm{N}$ per plant (from deficiency to luxury consumption, Oliet et al. 2004) while maintaining two different N-P-K balances by increasing the amounts of $\mathrm{P}$ and $\mathrm{K}$ within a formulation (Table 1). The treatments in the nursery were arranged in a completely randomized design. The heights and basal stem diameters were measured in 30 randomly selected 9-month-old seedlings per treatment, and they were sampled directly from the nursery containers. More details about the experimental layout and the results of the nursery study can be found in Oliet et al. (2005). 
Table 1. N, P and K amounts per plant as supplied by fertilizer treatments (the rates of each formulation per litre of substrate) and the heights and basal stem diameters of Acacia salicina seedlings after 9 months as affected by fertilization treatments.

\begin{tabular}{|c|c|c|c|c|c|}
\hline \multirow{2}{*}{$\begin{array}{l}\text { Formulation } \\
\text { Rate }\left(\mathrm{g} \mathrm{L}^{-1}\right)\end{array}$} & \multirow{2}{*}{$\begin{array}{c}\text { No fertilizer } \\
0.0\end{array}$} & \multicolumn{2}{|c|}{$9-13-18$} & \multicolumn{2}{|c|}{$16-8-9$} \\
\hline & & 1.5 & 3.25 & 3.25 & 7.0 \\
\hline \multicolumn{6}{|c|}{ Nutrient amounts per fertilizer treatment } \\
\hline $\mathrm{N}\left(\mathrm{mg}\right.$ seedling $\left.{ }^{-1}\right)$ & - & 31.0 & 67.2 & 119.6 & 257.6 \\
\hline $\mathrm{P}\left(\mathrm{mg}\right.$ seedling $\left.{ }^{-1}\right)$ & - & 19.6 & 42.3 & 26.0 & 56.1 \\
\hline $\mathrm{K}$ (mg seedling $\left.{ }^{-1}\right)$ & - & 51.5 & 111.6 & 55.9 & 120.3 \\
\hline \multicolumn{6}{|l|}{ Seedling morphology } \\
\hline Height $(\mathrm{cm})$ & $19.3 \mathrm{c}$ & $34.3 b$ & $40.2 \mathrm{ab}$ & $44.5 \mathrm{ab}$ & $49.7 \mathrm{a}$ \\
\hline Diameter (mm) & $2.3 \mathrm{c}$ & $3.1 \mathrm{~b}$ & $3.6 \mathrm{ab}$ & $4.1 \mathrm{a}$ & $4.4 \mathrm{a}$ \\
\hline
\end{tabular}

For seedling morphology, means with different letters within a row indicate significant differences $(\mathrm{n}=30)$.

On March 3, 1993, A. salicina seedlings were planted on a degraded plain $\left(2^{\circ} 20^{\prime} \mathrm{W}, 36^{\circ} 51^{\prime} \mathrm{N}\right.$, elevation $30 \mathrm{~m}$ ) of Almeria, Spain that was previously devoted to marginal croplands. According to FAO taxonomy, this soil belongs to a cambic arenosol group formed on calcareous parent material (Perez, 1989), with the first sandy horizon (95\% sand) at a $30 \mathrm{~cm}$ depth on a sandy-loamy horizon (66\% sand, $29 \%$ loam). The carbon $(0.5 \%)$ and the fertility of the profile are very low $(0.05 \%$ total $\mathrm{N}$,

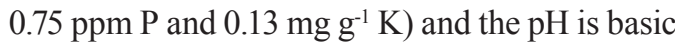
$\left(\mathrm{pH}_{\mathrm{H} 2 \mathrm{O}}\right.$ up to 8.5$)$ (Pérez, 1989). The mean annual rainfall and temperature of the area are $200.2 \mathrm{~mm}$ and $18.5^{\circ} \mathrm{C}$, respectively, with frequent strong southwest winds (Spanish National Institute of Meteorology reports, from data averaged from 1969 to 2001). The precipitation that fell during the study period was collected and measured by a pluviograph that was installed at the planting site. The annual rainfall from 1993 to 2001 averaged $160.5 \mathrm{~mm}$, with an average of $30 \mathrm{~mm}$ from May to September (Figure 1). The experimental site was fenced to restrict access to rodents and herbivores. Cross-plowing to a depth of $80 \mathrm{~cm}$ was performed prior to planting. The seedlings were planted in manually opened pits $(0.3 \mathrm{~m} \times 0.3 \mathrm{~m} \times 0.3 \mathrm{~m})$ with a spacing of $1.5 \mathrm{~m} \times 1.5 \mathrm{~m}$. The 10 factorial treatments (five nursery fertilization treatments $x$ two shelter treatments, with or without shelters at planting) were arranged in a randomized com- plete block design with four replications. The tree shelters were made of unventilated Tubex Standard ( tubes (Tubex Ltd., Aberdare, UK) which were constructed from twin solid-walled polypropylene with a light transmission coefficient of $45 \%$ (Oliet et al., 2003), and they were $0.6 \mathrm{~m}$ tall $\times 0.11 \mathrm{~m}$ wide. The experimental unit consisted of a row of 7 seedlings, and each block contained 10 rows. Manual weeding was conducted annually starting from 1993 and continuing through the whole period. Irrigation was applied via drip irrigation system with one drip line of $4.5 \mathrm{~L} \cdot \mathrm{h}^{-1}$ single emitters per seedling, which were installed close to the basal stem of the plant. The irrigation rate and frequency varied over the study period and over the season within a year, according to the water demand and developmental stage. During the first two years, the irrigation was aimed at optimizing survival by supplying adequate water for root growth; in subsequent years, water was applied to maintain soil moisture at stressing but non-lethal values, according to the soil texture and technical guidance (see the following section and www.irrometer.com). The water used here was taken from an adjacent well. A portable electrical conductivity (EC) meter was used to monitor the water salinity for every irrigation session. The $\mathrm{EC}$ in the irrigation water $\left(\mathrm{EC}_{\mathrm{w}}\right)$ ranged from 4.2 to $6.4 \mathrm{dS} \cdot \mathrm{m}^{-1}$, and the $\mathrm{pH}$ was between 7.5 and 8.0 during the nine-year study. According to the two sample analyses that 
were conducted during 2001, the average cation concentrations $\left(\mathrm{mg} \cdot \mathrm{L}^{-1} \pm \mathrm{EE}\right)$ were as follows: $\mathrm{K}$, 45.3 $\pm 2.7 ; \mathrm{Na}, 916.6 \pm 52.9 ; \mathrm{Ca}, 269.0 \pm 17.2 ;$ and $\mathrm{Mg}$, $194.6 \pm 8.8$. These values indicate a high SodiumAbsortion Ratio (SAR), rising up to 10.38. This value leads to severe restrictions in plant growth because of sodium toxicity (Ayers and Wescott, 1985). In addition, $\mathrm{EC}_{\mathrm{w}}$ values above $3 \mathrm{dS} \cdot \mathrm{m}^{-1}$ indicate a severe risk of adverse salinity effects on crops, which are only suitable for tolerant species (Ayers and Wescott, 1985).

\section{Measurements}

To measure the soil moisture to guide irrigation, tensiometers ( $\mathrm{R}$ model, Irrometer Company,
Riverside, CA, USA) were set up at two depths (45 and $90 \mathrm{~cm}$ ) at $15 \mathrm{~cm}$ from each tree. Four replicates were installed in randomly selected trees. Tensiometer readings (soil suction) indicate the matric potential of the soil (Muñoz-Carpena et al., 2005). The irrigation rate and frequency varied in accordance with the plantation stage and a specified threshold of soil suction. During the first two years after planting, the threshold was $15-25 \mathrm{kPa}$ at $45 \mathrm{~cm}$ and $30-40 \mathrm{kPa}$ at $90 \mathrm{~cm}$, which was maintained to avoid soil moisture levels that would induce highly stressful conditions (Migliaccio and $\mathrm{Li}, 2012$ ). After two years, the threshold was changed to $60-70 \mathrm{kPa}$ at $90 \mathrm{~cm}$ for the rest of the experiment. These settings were the primary guidelines used to account for changes in tree water demands. In addition, the irrigation amount was

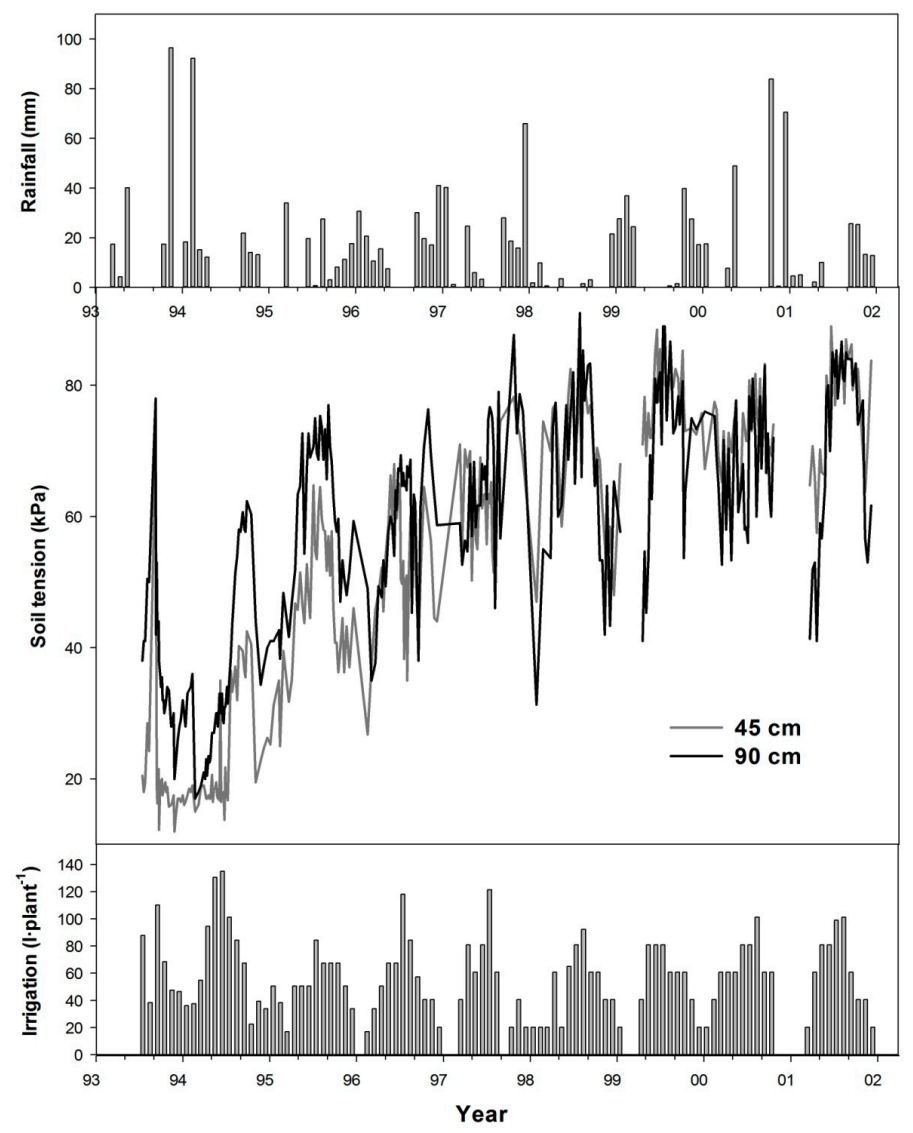

Figure 1. Monthly rainfall (top figure), maximum soil tension prior to irrigation at two soil depths (middle figure) and monthly irrigation rates on a per-plant basis (bottom figure) in an Acacia salicina plantation over nine years. 
controlled by varying the duration of the session. During the first year, frequent irrigation (every three to seven days, depending on the season) was conducted at $9 \mathrm{~L} \cdot$ tree $^{-1}$. Thereafter, irrigation was applied at rates of 17 to $20.2 \mathrm{~L} \cdot$ tree $^{-1}$ per session at longer intervals. This regimen was intended to promote deep rooting (Burman et al., 1991).

The seedling heights and basal stem diameters (BSD) of all the living plants were measured in June and October of 1993 and 1994, November 1995, January 1997, February 1999, December 2000, and January 2002. The survival percentage in each treatment replication was also assessed at the same time. The sturdiness quotient (height: BSD) was also calculated.

To characterize the soil salinity evolution over time, the depths, and distances from drip emitters soil samples were taken prior to planting (March 1993) and on three subsequent dates (October 1995, April 1999, and July 2001). The samples were taken with a $7.5 \mathrm{~cm}$ diameter auger that was 10 and $30 \mathrm{~cm}$ from the emitters near four trees (the same trees were used for each sampling date). Two 90-cm-deep auger holes were created at each distance from the emitter, and cores were collected at 0-30, 30-60 and 60-90 $\mathrm{cm}$. A composite sample was made from the two sampling points at the same depth. A total of 24 samples (4 replicates $\mathrm{x} 2$ distances $\mathrm{x} 3$ depths) were analyzed for the EC on each of the three sampling dates. Prior to the analysis, the coarse elements $(>2 \mathrm{~mm}$ ) were separated. Aqueous extracts of soil samples at a 1:5 soil-to-water ratio were prepared by adding $50 \mathrm{~mL}$ of deionized water to $10 \mathrm{~g}$ of soil in 200-mL screw-cap containers and then shaking the samples in a reciprocal shaker for one hour. Afterwards, each suspension was decanted and filtered. One drop of sodium hexametaphosphate $0.1 \%$ was added to prevent $\mathrm{CaCO}_{3}$ precipitation. The electrical conductivity at $25^{\circ} \mathrm{C}\left(\mathrm{EC}_{25}\right)$ was measured using a conductivity meter that was equipped for automatic temperature compensation. The instrument was tested with a $\mathrm{KCl}$ conductivity standard solution of $1.413 \mathrm{dS} \mathrm{m}^{-1}$. Providing that the electrical conductivity in the saturation extract $\left(\mathrm{EC}_{\mathrm{se}}\right)$ is the closest measurement to the plant's conditions in the soil (Richards, 1954), an approximate conversion from the $\mathrm{EC}$ in the 1:5 suspension $\left(\mathrm{EC}_{1: 5}\right)$ to $\mathrm{EC}_{\mathrm{se}}$ for $\mathrm{EC}_{1: 5}<1.0 \mathrm{dS} \mathrm{m}{ }^{-1}$ was calculated on the basis of the equation given by Visconti et al. (2010). For $\mathrm{EC}_{1: 5}$ values above $1.0 \mathrm{dS} \cdot \mathrm{m}^{-1}$, the quoted conversion equation loses accuracy and saturation extract measurements should be performed. However, in noting that only a few samples had $\mathrm{EC}_{1: 5}$ values that were slightly above that threshold, this operation was not performed.

\section{Statistical analyses}

For the nursery experiment, morphological analyses were conducted by one-way ANOVA (additional details in Oliet et al., 2005). Analyses of the survival and growth for the planting experiment were performed by two-way ANOVA with a general lineal model (the primary fixed factors consisted of nursery fertilization and a tree shelter at planting), with the treatment mean for each block comprising the experimental unit (each row consisted of 7 plants). For plantation survival percentages, the data were arcsinetransformed. The height, BSD, and sturdiness quotient data were log-transformed when ANOVA assumptions of normality and homoscedasticity were not met. A Kruskal-Wallis non-parametric test (K-W) was conducted on the data if their variances were not stabilized after log transformation. In any case, the data were reported as back-transformed means with standard errors. When the ANOVA statistics were significant, the differences between means were identified using Fisher's protected least significant differences test. The soil EC was analyzed using a repeated measure two-way ANOVA, with the depth and distance to the emitter as the primary fixed factors and the measurement date as the repeated factor. The effects were considered significant when $P \leq 0.05$. SPSS Version 15.00 was used for all statistical tests. 


\section{Results}

The shoot sizes of nursery seedlings increased steadily as greater $\mathrm{N}$ amounts were applied (Table 1). A more detailed explanation of the primary differences in nursery stock types among fertilization treatments can be found in Oliet et al. (2005).

\section{Irrigation, soil moisture and soil conductivity}

The soil tension followed a seasonal pattern prior to irrigation, with the maximum values being reached during the summer and the minimum values being reached in midwinter (Figure 1). During the first two years (1993-94), the maximum soil tension was kept low throughout the year, with pre-irrigation values below $20 \mathrm{kPa}$ (with the exception of August 1993, when a mishandled low rate of only $38.2 \mathrm{~L}$ was applied during this month) at $45 \mathrm{~cm}$ (Figure 1). November 1993 and February 1994 were the wettest months in terms of rainfall during the whole study period, which also contributed to reduced soil tension during the following months (Figure 1). After 1995, the maximum soil tension increased prior to irrigation and stabilized at approximately $70-80 \mathrm{kPa}$ in the summer at both depths (Figure 1). On average, $78.1 \mathrm{~L}^{\text {pplant }}{ }^{-1}$ per month was applied from June to September, with values ranging from 65.8 $\mathrm{L}$ plant ${ }^{-1}$ per month (1997) to $97.0 \mathrm{~L} \cdot$ plant $^{-1}$ per month (1994) (Figure 1).

The soil EC was not affected by the distance to the emitter or the depth (ANOVA data not shown). However, the soil conductivity was influenced significantly by time (the P-value for the repeated date factor was $\leq 0.001$ ) with increases from an overall mean of $1.2 \pm 0.1 \mathrm{dS} \cdot \mathrm{m}^{-1}$ (across depths and distances to drip emitters) to $5.4 \pm 0.4$ $\mathrm{dS} \cdot \mathrm{m}^{-1}$ (Figure 2). Despite the lack of significant differences among the depths $(\mathrm{P}=0.172)$, the soil conductance was always greater at the $60-90 \mathrm{~cm}$ depth, and the average values at the intermediate depth $(30-60 \mathrm{~cm})$ were the lowest.

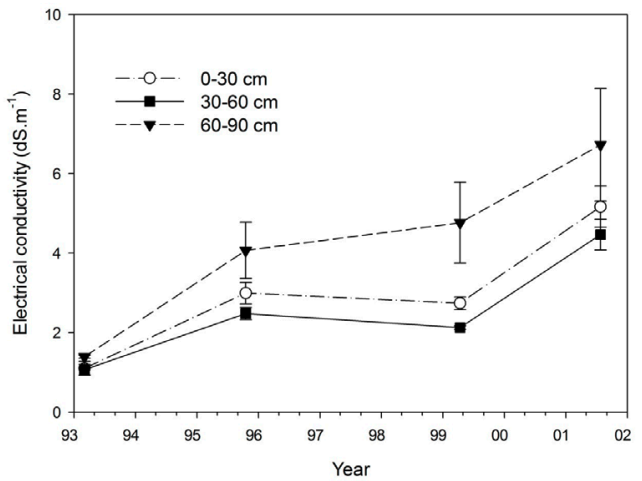

Figure 2. The soil electrical conductivity $( \pm$ SE. $n=8)$ evolution during the planting experiment as affected by the soil depth.

\section{Seedling response after planting}

Despite the fact that marginal differences were found prior to the seventh year, plant survival was not significantly affected by nursery fertilization until this amount of time had passed after planting (Table 2). By this time, the seedlings that were fertilized with $7 \mathrm{~g} \cdot \mathrm{L}^{-1}$ of Osmocote 16-8-9 showed significantly higher survival than the non-fertilized seedlings $(\mathrm{P}=0.05)$. Non-fertilized seedlings and those fertilized with 9-13-18 exhibited a notable drop in survival during the first two years after planting (Figure 3). By January 2002, the survival rate among the fertilized treatments ranged from $42.9 \pm 7.6 \%$ (non-fertilized seedlings) to $75.0 \pm 6.5$ $\%\left(7 \mathrm{~g} \mathrm{~L}^{-1}\right.$ of $16-8-9$, Figure 3). The tree shelters did not have a significant effect on survival at any date, although the seedlings that were protected with shelters tended to have higher survival and reached marginally significant differences during some years (Table 2 and Figure 3).

The height responses were significantly affected by nursery fertilization over the entire study (except in 1997, as shown in Table 2, Figure 3). At the ninth year after planting, non-fertilized trees or those that were fertilized at the lowest rate of 9-13-18 were $1.48 \mathrm{~m}$ tall on average, while those with the maximum rate of this formulation 


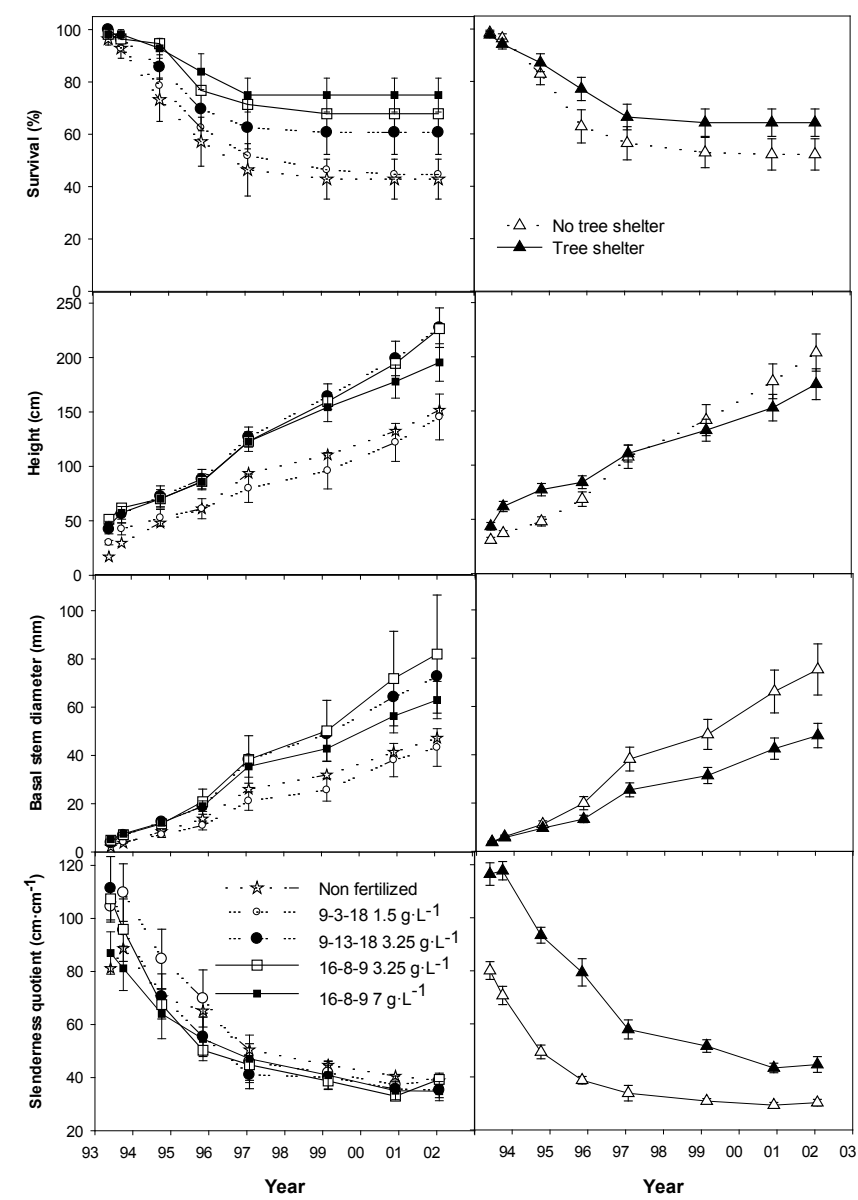

Figure 3. Post-planting survival, height, basal stem diameter and sturdiness quotient of Acacia salicina over nine years as affected by nursery fertilization $(\mathrm{n}=8)$ and tree shelters at planting $(\mathrm{n}=20)$. For clarity, only the SE of the maximum, minimum and intermediate fertilizer treatments are shown. In some cases, the SE bars are hidden by the symbol.

were $0.8 \mathrm{~m}$ taller (Figure 3 ). The tree shelters also had a significant and positive effect on the heights during the first three to four years (Table 2, Figure 3).

The basal stem diameter was significantly affected by nursery fertilization during the first two years after planting (Table 2). Thereafter, the results were non-significant, although nonfertilized trees and those that were fertilized at the lowest rate of 9-13-18 tended to have smaller BSDs than the trees in the other treatments (Figure 3). Tree shelter protection did not affect the
BSD until the third year after planting (Table 1). Thereafter, non-protected seedlings had larger BSDs than protected seedlings, with differences that increased over time (Figure 3).

Nursery fertilization affected the sturdiness quotient only during the first two years, whereas shelter protection affected the sturdiness quotient during the entire study period (Table 2). The trees that were kept in shelters had higher quotient values than unsheltered ones, although the differences were reduced with time until year eight, when the differences vanished (Figure 3). 
Table 2. F values and the statistical significance $(P)$ for the effects of shelter and nursery fertilization (Fert) on the postplanting survival, height, basal stem diameter (SD) and slenderness quotient over the nine-year monitoring period (June 1993-January 2002). Significant values are highlighted in bold.

\begin{tabular}{|c|c|c|c|c|c|c|c|c|c|}
\hline \multirow[b]{2}{*}{ Date } & \multirow[b]{2}{*}{ Effect } & \multicolumn{2}{|c|}{ Survival } & \multicolumn{2}{|c|}{ Height } & \multicolumn{2}{|c|}{ Basal SD } & \multicolumn{2}{|c|}{ Slenderness } \\
\hline & & $\mathrm{F}$ & $\mathrm{P}>\mathrm{F}$ & $\mathrm{F}$ & $\mathrm{P}>\mathrm{F}$ & $\mathrm{F}$ & $\mathrm{P}>\mathrm{F}$ & $\mathrm{F}$ & $\mathrm{P}>\mathrm{F}$ \\
\hline \multirow[t]{3}{*}{ Jun 93} & Shelter (S) & 0.36 & 0.554 & 136.21 & $\leq 0.001$ & 2.94 & 0.098 & 107.60 & $\leq 0.001^{2}$ \\
\hline & Fert (F) & 0.90 & 0.478 & 127.92 & $\leq 0.001$ & 91.81 & $\leq 0.001$ & 11.72 & $\leq 0.001^{2}$ \\
\hline & $\mathrm{F} \times \mathrm{S}$ & 0.31 & 0.310 & 7.07 & $\leq 0.001$ & 0.68 & 0.612 & 1.38 & $0.266^{2}$ \\
\hline \multirow[t]{3}{*}{ Oct 93} & Shelter (S) & 1.18 & 0.286 & 81.74 & $\leq 0.001$ & 0.90 & 0.352 & 174.08 & $\leq 0.001$ \\
\hline & Fert (F) & 0.74 & 0.573 & 18.92 & $\leq 0.001$ & 14.42 & $\leq 0.001$ & 7.014 & 0.001 \\
\hline & $\mathrm{F} \times \mathrm{S}$ & 2.53 & 0.063 & 1.67 & 0.185 & 0.22 & 0.925 & 0.72 & 0.584 \\
\hline \multirow[t]{3}{*}{ Oct 94} & Shelter (S) & 0.71 & 0.406 & 49.30 & $\leq 0.001$ & 2.08 & 0.161 & 205.08 & $\leq 0.001$ \\
\hline & Fert (F) & 2.66 & 0.055 & 6.01 & 0.001 & 3.74 & 0.015 & 5.28 & 0.003 \\
\hline & $\mathrm{F} \times \mathrm{S}$ & 0.72 & 0.582 & 1.27 & 0.305 & 0.34 & 0.848 & 0.73 & 0.578 \\
\hline \multirow[t]{3}{*}{ Nov 95} & Shelter (S) & 4.13 & 0.052 & 4.88 & 0.036 & 5.49 & 0.027 & 100.61 & $\leq 0.001^{2}$ \\
\hline & Fert (F) & 2.68 & 0.053 & 3.18 & 0.029 & 1.76 & 0.167 & 2.29 & $0.086^{2}$ \\
\hline & $\mathrm{F} \times \mathrm{S}$ & 0.63 & 0.644 & 0.67 & 0.615 & 0.59 & 0.676 & 0.67 & $0.62^{2}$ \\
\hline \multirow[t]{3}{*}{ Jan 97} & Shelter (S) & 1.04 & 0.316 & 0.06 & 0.813 & 5.08 & 0.032 & $20.41^{1}$ & $\leq 0.001^{1}$ \\
\hline & Fert (F) & 1.92 & 0.136 & 2.23 & 0.093 & 1.53 & 0.22 & $0.86^{1}$ & $0.931^{1}$ \\
\hline & $\mathrm{F} \times \mathrm{S}$ & 0.45 & 0.767 & 0.65 & 0.629 & 0.63 & 0.643 & & \\
\hline \multirow[t]{3}{*}{ Feb 99} & Shelter (S) & 2.93 & 0.098 & 0.35 & 0.558 & $5.16^{1}$ & $0.023^{1}$ & 73.11 & $\leq 0.001^{2}$ \\
\hline & Fert (F) & 3.43 & 0.022 & 3.17 & 0.029 & $7.85^{1}$ & $0.097^{1}$ & 0.58 & $0.679^{2}$ \\
\hline & FxS & 0.44 & 0.782 & 0.99 & 0.431 & & & 0.13 & $0.971^{2}$ \\
\hline \multirow[t]{3}{*}{ Dec 00} & Shelter (S) & 3.27 & 0.082 & 1.74 & 0.198 & $4.80^{1}$ & $0.028^{1}$ & 53.12 & $\leq 0.001$ \\
\hline & Fert $(\mathrm{Fe})$ & 3.60 & 0.020 & 3.01 & 0.036 & $7.66^{1}$ & $0.105^{1}$ & 1.73 & 0.172 \\
\hline & $\mathrm{F} \times \mathrm{S}$ & 0.40 & 0.809 & 0.99 & 0.43 & & & 0.67 & 0.616 \\
\hline \multirow[t]{3}{*}{ Jan 02} & Shelter (S) & 3.27 & 0.082 & 2.05 & 0.163 & $5.16^{1}$ & $0.023^{1}$ & 23.11 & $\leq 0.001^{2}$ \\
\hline & Fert (F) & 3.59 & 0.020 & 3.00 & 0.036 & $6.95^{1}$ & $0.139^{1}$ & 0.42 & $0.793^{2}$ \\
\hline & $\mathrm{F} \times \mathrm{S}$ & 0.40 & 0.809 & 0.92 & 0.466 & & & 0.50 & $0.737^{2}$ \\
\hline
\end{tabular}

${ }^{1}$ Chi-square and Kruskal-Wallis significant degree values.

${ }^{2}$ ANOVA conducted with log-transformed data.

\section{Discussion}

Irrigation management and soil conditions during the study period. Analyzing potential effects on seedling survival

During the first two years after planting, the irrigation threshold was lowered to reduce the planting check and to increase survival. Thereafter, the higher threshold still resulted in an annual irrigation of approximately $630 \mathrm{~L} \cdot$ plant $^{-1}$ because of the increasing evapo-transpiration associated with canopy growth. In addition, yearly changes in evaporative demand and rainfall are also important sources of variation (Figure 1). An average of $312 \mathrm{~L}$ of water was applied during the summer, which was lower than that of other experimental plantations in the Mediterranean (Pardos et al., 2015), but considerably higher than that of some experiments under arid conditions 
in which water was supplied manually at the root level through a pipe (Padilla et al., 2011). During the rest of the year, a considerable amount of water (approximately $50 \%$ of the yearly irrigation) was still applied during our experiment because of the low rainfall rates (Figure 1). The soil suction values that were registered three years after planting were often over $60 \mathrm{kPa}$, which can be considered highly stressful, but still not close to the wilting point (Irrometer Co. 2015).

Over time, there was an increase in the soil conductivity from negligible salinity values at planting (less than $2 \mathrm{dS} \cdot \mathrm{m}^{-1}$ ) to average values of over $5 \mathrm{dS} \cdot \mathrm{m}^{-1}$ at the end of the study, which could cause severe restrictions in crop yields (Richards, 1954). In performing observations by depth, the intermediate layer (30 to $60 \mathrm{~cm}$ ) had the lowest variation because in arid climates, the saline elements are washed down to deeper horizons or are dragged to the surface by capillary rise. This trend could change if the root system of the trees colonize this area of soil and stop most of the water from leaching. The surface horizon (0$30 \mathrm{~cm}$ ) had the greatest changes in conductivity, which was attributable to the combined action of irrigation, capillary rise, and rainfall. The deep horizon $(60-90 \mathrm{~cm})$ showed a continuous increase in conductivity with time; the total amount of salt in the soil was increased by irrigation; therefore, the salinization in this horizon may be accelerated by irrigating with saline water. This tendency could be significant for $A$. salicina because its roots colonize this deep horizon. If irrigation can be stopped once the plantation is well-established, the salinization of that deeper horizon should not be a problem for tolerant plants. However, when the water supply must be maintained, the irrigation volumes should ensure salt leaching (Ayers and Wescott, 1985) to maintain good soil conditions.

The overall survival of $A$. salicina after nine years was $58.2 \pm 4.0 \%$, which was not much higher than the survival from a similar experiment without irrigation (52.1 $\pm 3.2 \%$, Oliet et al., 2005). Because the soil suction values during these periods were below stressing conditions, we hypothesize that the negative effects of water salinity could also be expressed as the mean values of $\mathrm{EC}_{\mathrm{se}}$ that rapidly increased to over $3 \mathrm{dS} \cdot \mathrm{m}^{-1}$ (Figure 2). According to estimations from the literature (Santa Olalla-Mañas et al., 2005), under our soil conditions, values of $\mathrm{EC}_{\mathrm{se}}=0.5 \mathrm{dS} \mathrm{m}$ m $^{-1}$ such as those reached right after planting) corresponded to osmotic tension that was approximately equal to the soil suction (matric) tension; for extreme values of $\mathrm{EC}_{\mathrm{se}} \geq 3 \mathrm{dS} \mathrm{m}^{-1}$, the osmotic potential reached values above $220 \mathrm{kPa}$, which is much higher than those registered by the tensiometers (soil tension, Figure 1)

\section{Planting response: effects of nursery fertilization}

The survival of non or lowly fertilized $\left(1.5 \mathrm{~g} \mathrm{~L}^{-1}\right.$ 9-13-18) plants was significantly lower than that of plants receiving higher nursery fertilization rates, reflecting the superior performance of nutrient-loaded seedlings (Oliet et al., 2013). Under Mediterranean conditions, N-loaded seedlings develop deeper root systems and frequently survive better after planting (Villar-Salvador et al., 2012). This rooting could explain the superior survival that was found at a 16-8-9 formulation for both rates, despite the fact that the $\mathrm{P}$ and $\mathrm{K}$ contents are lower than that of the 9-13-18 formulation (Table 1). Significant differences among the fertilization treatments in our study despite irrigation reduced the planting check, indicating that certain levels of saline stress discriminate among nursery stock types with regards to survival. The similarities in certain mechanisms of saline stress resistance with drought stress resistance (Dawalibi et al., 2015) could explain common patterns of nursery fertilization responses to survival under irrigated and non-irrigated conditions (Oliet et al., 2005). In addition, high nutrient tissue concentrations can affect plant tolerance to salinity because of the important role of essential nutrients in adapting the osmotic potential of cells, the synthesis of protective proteins (Schulze et al., 2005) or even reducing oxidative stress caused by salt (Cakmak, 
2005). Moreover, the primary differences are related to the non-fertilized treatment, in which only $18.2 \pm 4.5 \%$ survived when it was not irrigated

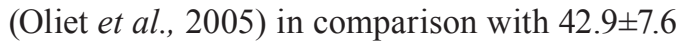
$\%$ survival when irrigated (current study). This result underscores the importance of nutrient reserves for survival under harsh conditions.

The growth rate of seedlings that were fertilized with 1.5 $\mathrm{g} \mathrm{L}^{-1}$ of 9-13-18 formulation was as low as that of non-fertilized seedlings (when raised in the nursery with no nutrient supply), revealing the nutritional insufficiency of the former treatment. Under no irrigation, the differences in the postplanting heights between low or non-fertilized and highly fertilized $A$. salicina seedlings in the nursery vanished after nine years (Oliet et al., 2005). In many studies, larger seedlings tend to maintain a size advantage over time in comparison with smaller seedlings (Rose and Ketchum 2003; Haase et al., 2006), and others have reported that the differences faded after a few years (Oliet et al., 2009). The lack of consistency between these results, apart from the differences in study duration, are associated with variability in the height growth response to a complex interaction between seedling attributes (size and nutritional status) and site characteristics such as soil fertility, drought, and competition (South et al., 2001; South et al., 2005; Oliet et al., 2009; Puértolas et al., 2012). It is particularly interesting to emphasize how, under our conditions, a small increase in fertilizer applications in the nursery (from 1.5 to 3.25 $\mathrm{g} \cdot \mathrm{L}^{-1}$ of $9-13-18$ ) provoked a $0.82 \mathrm{~m}$ difference in height after nine years in a plantation, and it seemed to increase or at least be maintained throughout the years in an anamorphic pattern (Logan and Shiver, 2006).

\section{Planting response: effects of tree shelters}

Tree shelters marginally improved the survival of A. salicina at the third year after planting and also towards the end of the trial (Table 2), suggesting that this species could benefit from protection. A similar result was found for non-irrigated seedlings in a simultaneous experiment under drought (Oliet et al., 2005). Although A. salicina is considered a pioneer species that is able to establish itself in harsh areas (Grigg and Mulligan, 1999; Jeddi et al., 2009), in our experiment, the shelters may have provided some continuous benefits by minimizing the transpirational demand of protected foliage associated with intense drying winds in the area (Bergez and Dupraz, 1997), especially after the third year when both the soil salinity and water tension was increased (Figures 1 and 2).

Most significant differences in the heights occurred when the mean lengths of protected shoots were below or starting to exceed the lengths of the shelters. During this time (around the first two years), the height was positively influenced by light reductions within the tubes that did not affect the growth in terms of diameter. Therefore, the light reduction within this shelter is not limiting the shoot growth during the first three-four years of planting because no allocation tradeoff between height and diameter growth was found. This response can be considered as a phototropic stimulus during the first seasons after planting rather than a reduction of resources (Devine and Harrington, 2008), and it is consistent with the marginal improvement in the survival of sheltered seedlings. Furthermore, the reduced height development in non-protected seedlings during the first year may be associated with transplanting stress as caused by desiccation in the very windy conditions of the experimental field. The reduction in the height growth rate of sheltered seedlings once the plant reached the top of the shelter can be explained by a new stress that was provoked by the transition between sheltered and unsheltered conditions, as was also observed in other studies (Oliet et al., 2000) and during the simultaneous non-irrigation experiment (Oliet et al., 2005). Interestingly, the height differences subsided in the fourth-fifth year, and under the non-irrigated conditions for a simultaneous experiment, the heights of both treatments never converged (Oliet et al., 2005). As often occurs 
with fast-growing species (Ponder, 2003), the size convergence of sheltered and unsheltered trees can be hastened by accelerating growth treatments such as irrigation. In our case, after the height gains of sheltered trees had vanished, the trend seemed to be shifting, with sheltered seedlings falling below those of the control. This pattern of null or negative gain responses in the height to silvicultural treatments at mid-term has been described by other authors (Logan and Shiver, 2006), and it is the opposite of that found for some nursery fertilization treatments in our study. By contrast, differences in stem diameters between protected and non-protected trees increased with time (especially after the third year of planting), which also occurred under non-irrigated conditions (Oliet et al., 2005). Because the shelters were not removed during our study, the continuous dynamic pressure on the basal stem provoked by the strong winds in the area enhanced the diameter growth of non-protected seedlings in comparison with protected seedlings (Coutand et al., 2008). The sturdiness quotient is an important morphological indicator of tree stability, and it is of interest when evaluating differences between sheltered and non-sheltered plants (Johansson, 2004). As a consequence, differences in the sturdiness quotient were high in comparison with other long-term studies (Oliet et al., 2000; Johansson, 2004). However, after nine years, the trunk development of trees in shelters was sufficient to support the canopy weight and could be removed (personal observation).

\section{Conclusions and management implications for future plantations}

Our results from nine years of experiments emphasize the importance of nursery fertilization in the medium-to-long-term development of $A$. salicina under dry conditions with saline irrigation. Nursery fertilization is a highly cost-effective approach, given that a relatively small increase in the rate multiplies during post-planting growth. A minimum of $83.7 \mathrm{mg} \mathrm{N}$ per seedling, which was applied as CRF and formulated as (N-P-K) 9-13-18 or 16-8-9, is needed to optimize survival and growth. Despite the windy conditions of the area, the use of tree shelters marginally improves survival under irrigation, but it does not affect the height growth and reduces the diameter in comparison with non-protected plants. The tree shelters seem to be more effective at promoting survival and growth under non-irrigated conditions. Therefore, if irrigation is planned, the use of tree shelters could be omitted to improve operational efficiency.

In comparison with the results of non-irrigated plantations, the use of saline water under the conditions in this experiment did not considerably improve the survival of the species, but it had a positive impact on the growth of surviving $A$. salicina trees. Given the ability of this species to improve microhabitats and soil conditions, the use of low-quality irrigation water can accelerate this restoration process (Jeddi et al., 2009), although increases in soil salinity associated with irrigation must be kept under maximum thresholds.

Our results suggest that monitoring plantations at mid-term provides extremely useful information regarding the effects of nursery practices and stock quality variables. It also provides information about cultural treatments that are applied in the field, or responses following planting, and should therefore be emphasized in experimental afforestation and reforestation trials.

The marked influence of strong winds in this area affects plant responses to treatments, and it emphasizes the fact that no general rules can be set for the application of postplanting treatments. However, a previous study of environmental conditions and the functional characteristics of the species must be conducted instead. 


\section{Acknowledgments}

We gratefully acknowledge the financial support of the National Institute for Agriculture and Food Technology and Research (INIA, Spanish
Department of Science and Innovation) through projects SC-94111 and OT98-001) and the Technical University of Madrid through its sabbatical program. The comments of three anonymous reviewers substantially improved this manuscript.

\title{
Resumen
}

\begin{abstract}
J.A. Oliet, R. Planelles, F. Artero y J.M. Domingo-Santos. 2016. Establecimiento de Acacia salicina bajo condiciones mediterráneas secas: efectos a medio plazo de la fertilización en vivero y de los protectores de árboles en un experimento con riego salino. Cien. Inv. Agr. 43(1):69-84. La restauración de áreas secas del área mediterránea es una tarea desafiante, ya que las duras condiciones abióticas impiden corregir el proceso retroalimentado de la degradación. La restauración activa mediante plantación es necesaria para detener dicho proceso. En esta trabajo se examina la influencia de la fertilización en vivero (dos formulaciones de fertilizante de liberación controlada aplicadas en dos dosis cada una) y de la protección de los árboles tras la plantación (empleando tubos protectores) sobre la respuesta a nueve años de Acacia salicina, aplicando riego con agua salina de baja calidad. La supervivencia global al final del periodo de estudio fue del 58,2\%, con valores de la conductividad eléctrica del extracto de saturación del suelo después de nueve años de $5.4 \mathrm{dS} \cdot \mathrm{m}^{-1}$. La supervivencia y el crecimiento en altura fue superior para los árboles fertilizados con dosis mayores de $1,5 \mathrm{~g} \cdot \mathrm{L}^{-1}$ de $9-13-18$, aunque las diferencias en supervivencia se tornaron significativas sólo a partir del séptimo año. El diámetro basal del tallo (DBT) de las plantas fertilizadas con las dosis más altas en vivero fue significativamente mayor que el de las fertilizadas a dosis menores durante los dos primeros años, aunque las diferencias se desvanecieron posteriormente. Las plantas protegidas con tubo protector tuvieron una supervivencia marginalmente superior, un crecimiento más rápido durante los cuatro primeros años y un menor DBT después del tercer año de plantación que las plantas no protegidas. En comparación con un estudio paralelo, realizado bajo condiciones de no riego, dicho factor redujo algunas diferencias entre tratamientos, pero incrementó otras. Estos resultados ponen de manifiesto la importancia del tamaño de la planta y de su estado nutricional de las plantas producidas en vivero, siendo las plantas altamente fertilizadas las que manifestaron una respuesta superior. Los estudios a largo plazo son cruciales para incrementar nuestra comprensión del comportamiento de las plantas y suministrar así mejores fundamentos para la recomendación de tratamientos.
\end{abstract}

Palabras clave: Calidad de planta, nutrición en plantas de vivero, plantación, restauración, tubos protectores.

\section{References}

Ayers, R.S., and D.W. Wescott. 1985. Water quality for agriculture. FAO, Irrigation and Drainage Paper no 29 rev. 1. Rome. 174 pp.

Bergez, J.E., and Z.C. Dupraz. 1997. Transpiration rate of Prunus avium L. seedlings inside an unventilated tree shelter. Forest Ecology and Management 97:255-264.
Burman, V., S. Kathju, B.K. Garg, and A.N. Lamiri. 1991. Water management of transplanted seedlings of Azadirachta indica in arid areas. Forest Ecology and Management 40:51-63.

Cakmak, I. 2005. The role of potassium in alleviating detrimental effects of abiotic stresses in plants. J. Plant Nutr. Soil Sci. 168:521-530.

Correal, E., P. Sánchez Gómez, and F. Alcaraz. 1988. Les especes ligneuses a usages multiples des zones 
arides Mediterraneannes. Agrimed Research Programme. Commission of European Communities. EUR 11770. Brussels, Belgium. p. 1-39.

Cortina, J., B. Amat, V. Castillo, D. Fuentes, F.T. Maestre, F.M. Padilla, and L. Rojo. 2011. The restoration of vegetation cover in the semi-arid Iberian southeast. Journal of Arid Environments 75:1377-1384.

Cortina, J., A. Vilagrosa, and R. Trubat. 2013. The role of nutrients for improving seedling quality in drylands New Forests 44:719-732.

Coutand, C., C. Dupraz, G. Jaouen, S. Ploquin, and B. Adam. 2008. Mechanical stimuli regulates the allocation of biomass in trees: demonstration with young Prunus avium trees. Annals of Botany 101:1421-1432.

Dawalibi, V., M.C. Monteverdi, S. Moscatello, A. Battistelli, and R. Valentini. 2015. Effect of salt and drought on growth, physiological and biochemical responses of two Tamarix species. iForest 8:772-779.

Devine, W., and C.A. Harrington. 2008. Influence of Four Tree Shelter Types on Microclimate and Seedling Performance of Oregon White Oak and Western Redcedar. Research Paper PNWRP-576. USDA Forest Service. Pacific NorthWest Research Station. 35 pp.

Grigg, A.H., and D.R. Mulligan. 1999. Biometric relationships for estimating standing biomass litterfall and litter accumulation of Acacia salicina on mined land in Central Queensland. Aust. J. Bot. 47:807-816.

Haase, D.L., R. Rose, and J. Trobaugh. 2006. Field performance of three stock sizes of Douglas-fir container seedlings grown with slow-release fertilizer in the nursery growing medium. New Forests 31:1-24.

Irrometer Co. 2015. Basics. Using the information. Available online at: www.irrometer.com (Website accessed: May, 2015).

Jacobs, D.F. 2011. Reforestation of a salvage-logged high-elevation clearcut: Engelman spruce seedling response to tree shelters after 11 growing seasons. West. J. Appl. For. 26:53-56.

Jeddi, K., J. Cortina, and M. Chaieb. 2009. Acacia salicina, Pinus halepensis and Eucalyptus occi- dentalis improve soil surface conditions in arid Southern Tunisia. Journal of Arid Environments 73:1005-1013.

Jiménez, M.N., F.B. Navarro, M.A. Ripoll, I. Bocio, and E. de Simón. 2005. Effect of shelter tubes on establishment and growth of Juniperus thurifera L. (Cupressaceae) seedlings in Mediterranean semi-arid environment. Ann. For. Sci. 62:717-725.

Johansson, T. 2004. Changes in stem taper for birch plants growing in tree shelters. New Forests 27:13-24

Le Houérou, H.N. 2000. Utilization of fodder trees and shrubs in the arid and semiarid zones of west Asia and North Africa. Arid Soil Research and Rehabilitation 14:101-135.

Logan, S.R., and B.D. Shiver. 2006. Adjusting slash pine growth and yield for silvicultural treatments. p. 328-332. In: Connor, Kristina F. (eds.). 2006. Proceedings of the 13th biennial southern silvicultural research conference. Gen. Tech. Rep. SRS-92. Asheville, NC: U.S. Department of Agriculture, Forest Service, Southern Research Station.

Migliaccio, K.W., and W.C. Li. 2012. Irrigation Scheduling for Tropical Fruit Groves in South Florida. Agricultural and Biological Engineering Department, Florida Cooperative Extension Service, Institute of Food and Agricultural Sciences, University of Florida. TR001. Available online at. http://edis. ifas.ufl.edu (Website accessed: May, 2015).

Ministerio de Agricultura, Alimentación y Medio Ambiente. 2013. Real Decreto 630/2013, de 2 de agosto, por el que se regula el Catálogo español de especies exóticas invasoras. Madrid, España. Boletín Oficial del Estado 185. Last modified May 19, 2015.

Muñoz-Carpena, R., M.D. Dukes, C.Y. Li, and W. Klassen. 2005. Field comparison of tensiometer and granular matrix sensor automatic drip irrigation on tomato. HortTechnology 15:584-590.

Oliet, J.A, R. Planelles, M. López-Arias, and F. Artero. 2000. Efecto de la fertilización en vivero y del uso de protectores en plantación sobre la supervivencia y el crecimiento durante seis años de 
una repoblación de Pinus halepensis. Cuadernos de la S.E.C.F. 10:69-77.

Oliet, J.A., R. Navarro, and O. Contreras. 2003. Evaluación de la aplicación de mejoradores y tubos en repoblaciones forestales. Manuales de Restauración Forestal N ${ }^{\circ}$ 2. Consejería de Medio Ambiente de la Junta de Andalucía, Sevilla, España. 234 pp.

Oliet, J.A, R. Planelles, M.L. Segura, F. Artero, and D.F. Jacobs. 2004. Mineral nutrition and growth of containerized Pinus halepensis seedlings under controlled-release fertilization. Scientia Horticulturae 103: 113-129.

Oliet, J.A., R. Planelles, F. Artero, and D.F. Jacobs. 2005. Nursery fertilization and tree shelters affect long-term field response of Acacia salicina Lindl. planted in Mediterranean semiarid conditions. Forest Ecology and Management 215:339351.

Oliet, J.A., R. Planelles, F. Artero, R. Valverde, D.F. Jacobs, and M.L. Segura. 2009. Field performance of Pinus halepensis planted in Mediterranean arid conditions: relative influence of seedling morphology and mineral nutrition. New Forests 37:313-331.

Oliet, J.A., J. Puértolas, R. Planelles, and D.F. Jacobs. 2013. Nutrient loading of forest tree seedlings to promote stress resistance and field performance: a Mediterranean perspective. New Forests 44:649-669.

Padilla, F.M., R. Ortega, J. Sánchez, and F.I. Pugnaire. 2009. Rethinking species selection for restoration of arid shurblands. Basic and Applied Ecology 10:640-647.

Padilla, F.M., J.D. Miranda, R. Ortega, M. Hervás, J. Sánchez, and F.I. Pugnaire. 2011. Does shelter enhance early seedling survival in dry environments? A test with eight Mediterranean species. Applied Vegetation Science 14:31-39.

Pardos, M., R. Calama, C. Mayoral, G. Madrigal, and M. Sánchez-Gómez. 2015. Addressing posttransplant summer water stress in Pinus pinea and Quercus ilex seedlings. iForest 8:348-358.

Pérez, A. 1989. Proyecto LUCDEME. Mapa de suelos escala 1:100.000. Almería-1045 Ministerio de Agricultura Pesca y Alimentación. ICONA.
Consejo Superior de Investigaciones Científicas. Madrid, España.

Piñeiro, J., F.T. Maestre, L. Bartolomé, and A. Valdecantos. 2013. Ecotechnology as a tool for restoring degraded drylands: a meta-analysis of field experiments. Ecological Engineering 61:133- 144.

Ponder, F. 2003. Ten-year results of tree shelters on survival and growth of planted hardwoods. North. J. Appl. For. 20:104-108.

Puértolas, J., J.A. Oliet, D.F. Jacobs, L.F. Benito, and J.L. Peñuelas. 2010. Is light the key factor for success of tube shelters in forest restoration plantings under Mediterranean climates? Forest Ecology and Management 260:610-617.

Puértolas, J., D.F. Jacobs, L.F. Benito, and J.L. Peñuelas. 2012. Cost-benefit analysis of different container capacities and fertilization regimes in Pinus stock-type production for forest restoration in dry Mediterranean areas. Ecological Engineering 44:210-215.

Rehman, S., R.N. Loescher, and P.J. Harris. 1999. Dormancy breaking and germination of $\mathrm{Aca}$ cia salicina Lindl. Seeds. Seed Sci. \& Technol. 27:553-557.

Richards, L.A. (ed.). 1954. Diagnosis and Improvement of Saline and Alkali Soils. USDA. Hand Book No 60.160 pp.

Rose, R., and J.S. Ketchum. 2003. Interaction of initial seedling diameter, fertilization and weed control on Douglas-fir growth over the first four years after planting. Ann. For. Sci. 60:625-635.

Santa Olalla-Mañas, F.M., P. López Fuster, and A. Calera Belmonte. 2005. Agua y Agronomía. Mundi-Prensa. Madrid, España. 606 pp.

Schulze, E.D., E. Beck, and K. Müller-Hohenstein. 2005. Plant Ecology. Springer, Berlin. 702 pp.

South, D.B., J.L. Rakestraw, and G.A. Lowerts. 2001. Early gains from planting large diameter seedlings and intensive management are additive for loblolly pine. New Forests 22:97-110.

South, D.B., S.W. Harrisa, J.P. Barnett, M.J. Hainds, and D.H. Gjerstad. 2005. Effect of container type and seedling size on survival and early height growth of Pinus palustris seedlings in Alabama, USA. Forest Ecology and Management 204:385-398. 
Tilstone, G.H., N.M. Pasiecznik, P.J. Harris, and S.J. Wainwright. 1998. The growth of multipurpose tree species in the Almeria province of Spain and its relationship to native plant communities. International Tree Crops Journal 9:247-259.

Vallejo, R.V., A. Smanis, E. Chirino, D. Fuentes, A. Valdecantos, and A. Vilagrosa. 2012. Perspectives in dryland restoration: approaches for climate change adaptation. New Forests 43:561579.

Vázquez de Castro, A., J.A. Oliet, J. Puértolas, and D.F. Jacobs. 2014. Light transmissivity of tube shelters affects root growth and biomass allocation of Quercus ilex L. and Pinus halepensis Mill. Annals of Forest Science 71:91-99.
Villar-Salvador, P., J. Puértolas, B. Cuesta, J.L. Peñuelas, M. Uscola, N. Heredia-Guerrero, and J.M. Rey Benayas. 2012. Increase in size and $\mathrm{N}$ concentration enhances seedling survival in Mediterranean plantations. Insights from an ecophysiological conceptual model of plant survival. New Forests 43:755-770.

Visconti, F., J.M. de Paz, and J.L. Rubio. 2010. An empirical equation to calculate soil solution electrical conductivity at $25{ }^{\circ} \mathrm{C}$ from major ion concentrations. European Journal of Soil Science 61:980-993.

Yokota, S. 2003. Relationship between salt tolerance and proline accumulation in Australian acacia species. Journal of Forest Research 8:89-93. 